DOI: https://doi.org/10.15407/techned2018.04 $=\underline{005}$

\title{
GREEN'S FUNCTIONS OF AXISYMMETRIC ELECTRIC AND MAGNETIC FIELDS ABOVE FLAT BOUNDARY SURFACE
}

Journal

Publisher

ISSN

Issue

Pages
Tekhnichna elektrodynamika

Institute of Electrodynamics National Academy of Science of Ukraine 1607-7970 (print), 2218-1903 (online)

No 4, 2018 (July/August)

$5-9$

\section{Author}

\section{V.M. Mikhailov*}

National Technical University «Kharkiv Polytechnic Institute»,

Kyrpychova st., 2, Kharkiv, 61002, Ukraine,

e-mail: valery.m.mikhailov@gmail.com

* ORCID ID : http://orcid.org/0000-0001-7989-5932

\section{Abstract}

Green's functions for axisymmetric electric and magnetic fields generated by annular elementary electric and fictitious magnetic charges and current, which are located above flat boundary of conducting, ideal ferromagnetic and ideal superconducting half-space are obtained. Verify the correctness of obtained functions is carried out by comparative calculations. Equipotential and power lines of considered fields and distributions of electric field strength and magnetic induction on the boundary are given. It's shown that Green's functions are the solutions of the problem of field continuation from flat boundary, which are used to determine profiles of electrodes and solenoids. Hankel's integral transformations of boundary field 
distributions conditioned by annular sources are obtained. References 10, figures 3, table 1.

Key words: Green's function, annular charge, annular current, flat boundary, conducting half-space, ideal super-conducting half-space, problem of field continuation.

Received: 02.03.2018

Accepted: 12.03.2018

Published:

\section{References}

1. Grinberg G.A. Selected questions of mathematical theory of electric and magnetic phenomena. Moskva-Leningrad: Izd. AN SSSR, 1948. 728 p. (Rus)

2. Lebedev N.N., Skalskaya I.P., Uflyand Ya.S. Compilation of mathematical physics problems. Moskva: GITTL, 1995. 420 p. (Rus)

3. Konovalov O.Ya., Mikhailov V.M., Petrenko M.P. Solution of the problem of the magnetic field continuation from cylindrical surface by using Green's function. Tekhnichna Elektrodynamika 2016.

No 5. Pp. 11-13. (Rus) DOI:

https://doi.org/10.15407/techned2016.05.011

4. Mikhailov V.M. Continuation of magnetic flux and potential of axisymmetric fields from flat surface. Elektrichestvo. 2002. No 10. Pp. 58-64. (Rus)

5. Mikhailov V.M. Green's function and integral equations of axisymmetryc fields of devices with long cylinders. Elektrichestvo. 1991. No 10. Pp. 38-42. (Rus)

6. Morozov A.I., Solovyev L.S. Geometry magnetic field. Voprosy teorii plazmy. 1963. Issue 2. Pp. 3-91. (Rus)

7. Mors F.M., Feshbakh G. Methods of theoretical physics. Vol.1. Moskva: Inostrannaia Literatura, 1958. 931 p. (Rus) 
8. Neiman L.R., Demirchyan K.S. Theoretical fundamentals of electrical engineering. Vol 2. Leningrad: Energoizdat, 1982. 416 p. (Rus)

9. Smite V. Electrostatics and Electrodynamics. Moskva: Inostrannaia Literatura, 1954. 604 p. (Rus)

10. Yanke E., Emde. F., Lesh F. Special functions (formulas, graphs, tables). Moskva: Nauka, 1977. 344 p.(Rus)

PDF 